\title{
Analisis Guncangan Eksternal Terhadap Indikator Moneter dan Makro Ekonomi Indonesia
}

\author{
Nora Ria Retnasih, Grisvia Agustin, Dwi Wulandari \\ Program Pascasarjana, Program Studi Ilmu Ekonomi, Universitas Negeri Malang \\ Email: rhaarianto@gmail.com
}

Diterima: 2 April 2016; Disetujui: 18 Agustus 2016; Dipublikasikan: 4 November 2016 Permalink/DOI: http://dx.doi.org/10.17977/um002v8i22016p101

\begin{abstract}
In accordance with the theory of a small open economy, Indonesia including the category of countries whose economies are vulnerable to the effects from another country who has a close working relationship, such as the United States of America (USA). The purpose of this study was to measure the effect of federal funds rate on BI rate; and BI rate implications on exchange rate, economic growth, and consumer price index. This type of research is quantitative. Collecting data using techniques of documentation provided by the Federal Reserve Data (FRED), Bank Indonesia (BI), and Bureau Central of Statistic (BPS). The analysis tool using Stationarity test, stability models test, determination of lag, and Structural Vector Autoregressive Models (svar). Based on the results of SVAR estimation can be concluded that Federal Fund Rate have a positive and significant effect on BI rate. By implication, BI rate have a positive and significant effect on exchange rate. However, BI rate has also positive but no significant effect on GDP. Neither CPI, the effect is negative and significant.
\end{abstract}

Keywords: Federal Fund Rate, Exchange Rate, Gross Domestic Product,

Consumer Prices Index, BI Rate

JEL Classification: E52, E60

\section{PENDAHULUAN}

Keterbukaan sistem ekonomi yang dimiliki sebuah negara mengakibatkan hubungannya dengan negara lain menjadi salah satu aspek penting yang mempengaruhi kemajuan perekonomian negara tersebut. Menurut Atmadja (2001) negara yang berperekonomian terbuka (open economy country) adalah negara yang telah membuka diri terhadap dunia internasional dengan turut terlibat dalam berbagai kegiatan perdagangan baik barang, jasa, maupun transaksi modal dengan negara lain. Selain itu, Negara yang menganut perekonomian terbuka juga telah mengintegrasikan diri ke dalam kancah perekonomian global. Contohnya adalah hubungan bilateral antara Indonesia dan Amerika Serikat (AS) pada saat ini jauh lebih erat dibandingkan dengan yang terjadi pada masa awal kemerdekaan.

Keeratan hubungan kedua negara ini dapat dilihat dari arus perdagangannya yang semakin besar setiap tahunnya. Indonesia dalam hal ini merupakan negara dengan perekonomian terbuka kecil. Menurut Hermawan (2011) kategori kecil ini terbentuk karena naik-turunnya kinerja perekonomian Indonesia tidak dapat mempengaruhi perubahan harga dunia. Sehingga dalam hal ini, Indonesia merupakan negara penerima harga (price taker) dalam aktivitas ekonomi dunia. 


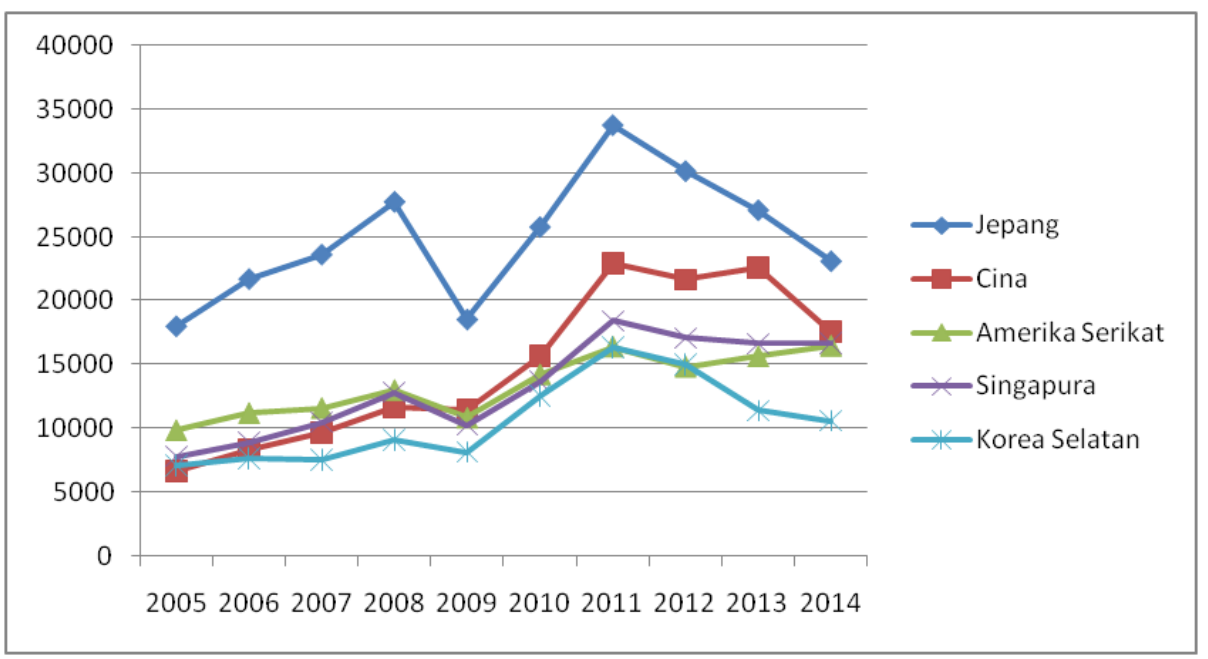

Gambar 1. Kinerja Ekspor Indonesia

Sumber: BPS-data diolah

Gambar 1 menjelaskan lima negara yang menjadi mitra dagang utama Indonesia. Menurut data yang diterbitkan Badan Pusat Statistik (BPS) (2016) dijelaskan bahwa AS merupakan Negara tujuan ekspor terbesar ketiga Indonesia dengan nilai perdagangan rata-rata sebesar 13.442,36 (Juta USD) setiap tahunnya. Keeratan hubungan di antara kedua negara dapat memberikan dampak positif terhadap kinerja ekonomi Indonesia. Nezky (2013) menjelaskan bahwa perubahan nilai perdagangan yang semakin besar baik melalui ekspor maupun impor sebuah negara akan turut berpengaruh pada peningkatan pertumbuhan ekonominya. Namun, disisi lain hal ini juga dapat memberi dampak negatif dengan semakin besarnya tingkat ketergantungan Indonesia sebagai negara berkembang terhadap AS sebagai negara maju yang menjadi mitra kerjasamanya. Al-Arif dan Tohari (2006) menjelaskan bahwa perubahan kondisi ekonomi global yang kurang menguntungkan, seperti kenaikan harga minyak dunia, krisis finansial, dan pelemahan ekonomi negara-negara maju menyebabkan upaya dalam menjaga stabilitas ekonomi dalam negeri menjadi terganggu.

Pada rentang waktu tahun 2005 sampai dengan tahun 2015, sempat terjadi beberapa fenomena-fenomena ekonomi yang mengakibatkan fluktuasi perekonomian global dan berdampak pada kinerja moneter dan makro ekonomi Indonesia. Pertama, kenaikan harga minyak dunia pada tahun 2005, 2008, dan 2011. Menurut Nizar (2012) kenaikan harga minyak dunia mengakibatkan peningkatan pada pertumbuhan ekonomi dan inflasi di Indonesia. Selain itu juga mendepresiasikan nilai tukar Rupiah terhadap USD dan pada akhirnya direpon dengan peningkatan BI rate. Kedua, krisis finansial global pada kisaran tahun 2007/2008 yang dikenal dengan krisis subprime mortgage. Ketiga, terjadinya pelemahan ekonomi negara-negara maju pada kisaran tahun 2013/2014.

Serangkaian fenomena-fenomena global yang terjadi ini mengakibatkan turunnya kinerja ekonomi AS yang diiringi dengan turunnya daya beli masyarakatnya. Ibrahim dkk (2014) menjelaskan sejalan dengan pelemahan ekonomi dunia, volume perdagangan dan harga komoditas juga menunjukkan pelemahan dan berimbas langsung pada negara mitra dagang yang pertumbuhan 
ekonominya bergantung pada permintaan eksternal sehingga juga turut berpengaruh pada indikator ekonomi lainnya.

Menurut Asari dkk (2011) nilai tukar memainkan peran vital dalam tingkat perdagangan negara yang terlibat dalam ekonomi pasar bebas dunia. Al-Arif dan Tohari (2006) menambahkan bahwa pada umumnya negara dengan perekonomian terbuka akan menganut sistem nilai tukar mengambang bebas, dimana secara teoritis transmisi dampak guncangan ekonomi global terhadap ekonomi domestik terjadi melalui jalur nilai tukar. Menurut Data Statistik Ekonomi Keuangan Indonesia (SEKI) yang diterbitkan oleh Bank Indonesia (BI) (2016) menjelaskan bahwa pada saat terjadi krisis finansial AS Rupiah terus terdepresiasi dan mencapai $\mathrm{Rp}$ 12.000. Pada saat yang bersamaan laju PDB berada pada titik terendahnya mencapai $-3,6$ persen. Menurut Bodenstein (2009) terjadinya guncangan luar negeri akan berdampak pada penurunan permintaan luar negeri, sehingga menurunkan aktivitas ekspor yang berdampak pada depresiasi mata uang dan turunnya pertumbuhan ekonomi. Berdasarkan perhitungan statistika oleh Bank Mandiri dalam Kementrian Perdagangan (2013) diperoleh hasil bahwa setiap penurunan 1 persen pertumbuhan PDB AS, maka pertumbuhan ekonomi Indonesia akan turun sebesar 0,11 persen. Indikator makro-ekonomi lain yang juga terpengaruh oleh guncangan ekonomi global adalah indeks harga konsumen (IHK). Pada saat terjadi krisis finansial AS IHK mengalami peningkatan dibandingkan tahun sebelumnya mencapai 132,725 persen dengan tingkat inflasi sebesar 11,06 persen.

BI selaku otoritas moneter Indonesia menggunakan kebijakan moneter sebagai upaya dalam menjaga stabilitas moneter dan makro dalam negeri. Ada banyak instrumen yang dapat digunakan, salah satunya melalui penetapan tingkat suku bunga. Sejak tahun 2005, BI rate digunakan sebagai instrumen utama dalam pengendalian moneter di Indonesia. Pemilihan suku bunga ini didasarkan pada beberapa kriteria sesuai penjelasan Mishkin (2008) yaitu dapat diamati, diukur, dikendalikan, dan dapat mempengaruhi variabel-variabel tujuan dengan cara yang dapat diprediksi.

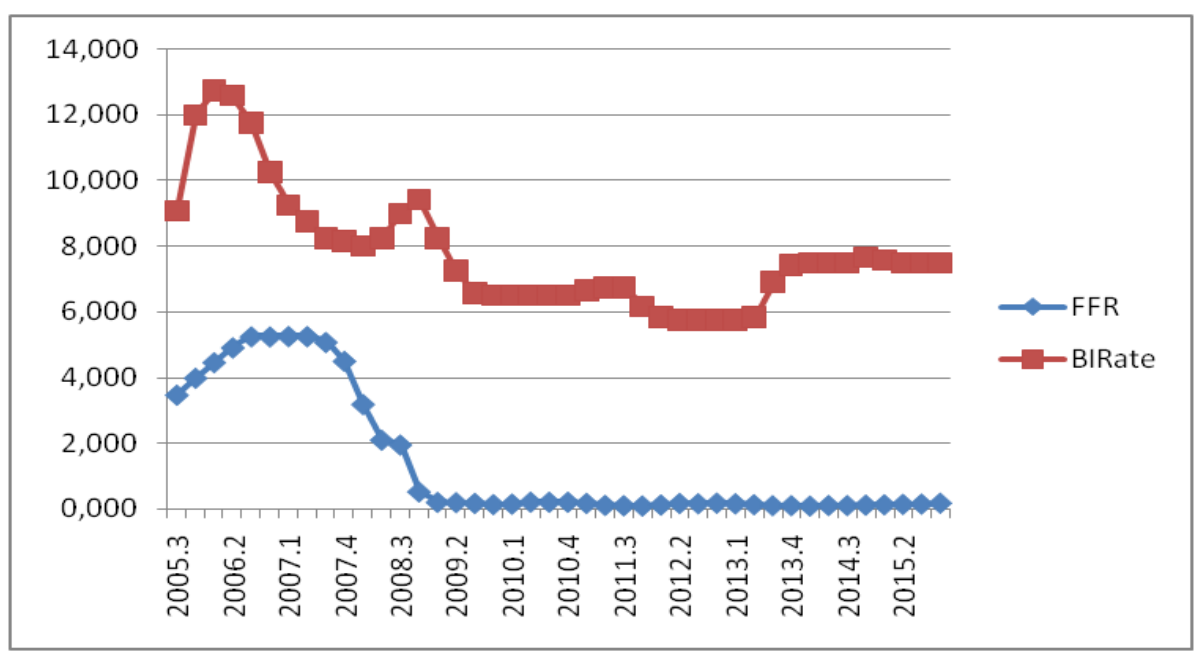

Gambar 2. Perbandingan Federal Fund Rate dan BI Rate Sumber: Federal Reserve Data dan BPS, data diolah 
Pada umumnya penetapan besarnya BI rate tidak hanya memperhatikan kondisi makro-ekonomi dalam negeri saja, tetapi juga mempertimbangkan pergerakan dari besarnya tingkat suku bunga dunia (federal fund rate/FFR). Menurut Hilton dan Hrung (2007) FFR merupakan suku bunga AS yang mengacu pada tingkat suku bunga bank dalam membayar bank lain atas pinjaman saldo cadangan yang diadakan oleh Federal Reserve (The Fed) selaku bank sentral AS.

Gambar 2 menunjukkan perbandingan BI rate dan FFR. Pada umumnya kenaikan dalam FFR akan direspon dengan kenaikan BI rate. Manakala The Fed menetapkan kebijakan moneter yang ekspansif sebagai upaya untuk meredam dampak krisis yang terjadi, FFR menurun dari 5,02 persen pada Agustus 2007 secara bertahap hingga menjadi 0,16 persen pada Desember 2008. Pada kurun waktu yang bersamaan BI juga turut merespon dengan menurunkan BI rate dari 8,25 persen menjadi 8 persen sampai dengan April 2008 serta meningkatkan BI rate kembali hingga menjadi 9,25 persen pada akhir 2008 .

Secara umum, untuk menyesuaikan dinamika perekonomian global dan mempertahankan stabilitas ekonomi dalam negeri, BI melakukan penyesuaian tingkat suku bunganya terhadap pergerakan FFR. Warjiyo dkk (2003) menjelaskan bahwa mobilitas dana dari dan ke luar negeri akan mengakibatkan perubahan dalam tingkat suku bunga dalam menyesuaikan jumlah uang yang beredar agar sesuai dengan kebutuhan perekonomian. Hal ini juga disebutkan dalam model Mundell-Fleming yang menyatakan bahwa perekonomian terbuka kecil dapat meminjam atau memberi pinjaman sebanyak yang diinginkan di pasar keuangan dunia dan sebagai akibatnya tingkat bunga perekonomian Indonesia ditentukan oleh tingkat suku bunga dunia (Mankiw, 2007). Sedangkan secara khusus, menurut Khawaga dkk (2013) perubahan dalam tingkat suku bunga sesuai dengan teori International Fisher Effect dapat mempengaruhi perubahan dalam nilai tukar negara tersebut. Selain itu, Sudarjah dan Yusuf (2008) menyatakan bahwa selain mempengaruhi pergerakan nilai tukar, penetapan BI rate sesuai dengan model Taylor rule mempunyai dua cakupan dalam target moneter yaitu inflasi yang rendah dan stabil, serta pertumbuhan output yang berkelanjutan.

Keterbukaan ekonomi Indonesia serta besarnya tingkat ketergantungannya terhadap negara maju, mengakibatkan perencanaan dan pelaksanaan kebijakan moneter tidak dapat berjalan secara independen. Dalam setiap penetapan kebijakannya BI juga turut mempertimbangkan fluktuasi kondisi ekonomi AS. Hal ini berkenaan dengan aliran dana masuk dan keluar akibat transaksi perdagangan dan keuangan yang dilakukan. Aliran dana ini akan mempengaruhi jumlah uang beredar, suku bunga, nilai tukar yang pada akhirnya akan berpengaruh pada pertumbuhan ekonomi dan tingkat harga. Kekhawatiran terhadap dampak negatif yang mungkin ditimbulkan akibat keeratan hubungan kerjasama dua negara ini melatarbelakangi penulis untuk menganalisis dampak kebijakan moneter AS melalui FFR terhadap kebijakan moneter Indonesia (BI Rate) dan implikasinya pada nilai tukar, pertumbuhan ekonomi (PDB), dan Indeks Harga Konsumen (IHK).

\section{KAJIAN PUSTAKA \\ Kebijakan Moneter}

Kebijakan moneter adalah kebijakan yang dilakukan bank sentral sebagai otoritas moneter suatu negara berupa pengendalian besaran moneter untuk 
mencapai tujuan perkembangan kegiatan ekonomi yang telah ditetapkan (Warjiyo dkk, 2003). Selain itu, menurut Mishkin (2008) tujuan lain dari kebijakan moneter yaitu penyediaan lapangan pekerjaan, pertumbuhan ekonomi, stabilitas pasar keuangan, stabilitas suku bunga, dan stabilitas di pasar valuta asing. Dalam upaya mewujudkan tujuan yang telah ditetapkan, instrumen kebijakan moneter yang dapat digunakan sebagai alat operasi moneter meliputi, operasi pasar terbuka, fasilitas diskonto, giro wajib minimum, intervensi di pasar valas dan himbauan moral.

\section{Stabilitas Makroekonomi}

Samuelson dan Nordhaus (2004) menjelaskan bahwa ilmu makroekonomi merupakan kajian terkait dengan kinerja perekonomian secara keseluruhan dengan dua cakupan tema yaitu, pertama terkait fluktuasi jangka pendek dalam output, lapangan pekerjaan, dan harga-harga yang dikenal dengan siklus bisnis. Kedua, terkait tren jangka panjang dalam output dan standar hidup yang dikenal dengan pertumbuhan ekonomi. Lebih lanjut dijelaskan, stabilitas ekonomi dapat tercermin melalui pencapaian output nasional yang tinggi dan pertumbuhannya yang tinggi. Selain itu, juga dapat dilihat melalui ketersediaan lapangan kerja dan jumlah pengangguran yang rendah.

\section{Perekonomian Terbuka}

Menurut Mankiw (2007) negara dengan perekonomian terbuka adalah negara yang perekonomiannya terintegrasi dengan dunia yang ditandai dengan adanya aktivitas ekspor maupun impor barang dan jasa serta terlibat dalam kegiatan di pasar modal dunia. Samuelson dan Nordhaus (2004) menjelaskan bahwa sistem perekonomian internasional yang berjalan mulus akan memberikan sumbangan pertumbuhan ekonomi yang cepat, sedangkan manakala terjadi gejolak ekonomi internasional dapat berimbas pada kehancuran pada arus perdagangan dan finansial.

\section{Model Mundell-Fleming}

Menurut Mankiw (2007) model Mundell-Fleming dapat digunakan untuk menganalisa kebijakan yang efektif dalam penerapan sistem nilai tukar mengambang. Al-Arif dan Tohari (2006) menambahkan bahwa dalam teori ini dikemukakan bahwa kebijakan moneter yang ekspansif dapat mempengaruhi kenaikan output di suatu negara dan mengakibatkan output di negara lain menjadi negatif. Transmisi model Mundell-Fleming ini dapat terjadi melalui jalur perdagangan, dimana suatu negara akan menurunkan suku bunga, mendepresiasikan nilai tukar, dan menciptakan persaingan kompetitif. Sehingga negara tersebut akan mengalami surplus neraca perdagangan akibat meningkatnya produk yang diekspor (dan menurunnya impor dari negara lain).

\section{Taylor Rule}

Woodford (2001) menyatakan bahwa Taylor rule merupakan model yang digunakan untuk menstabilkan inflasi dan kesenjangan output melalui kebijakan moneter yang optimal. Terdapat tiga hal yang harus diperhatikan dalam model Taylor Rule. Pertama, tingkat suku bunga bank merupakan instrumen kebijakan moneter yang digunakan. Efisiensi kebijakan ini secara tidak langsung akan 
ditunjukkan melalui nilai output dan inflasi. Kedua, yang menjadi sasaran akhir adalah inflasi yang rendah. Ketiga, sasaran lainnya adalah pendapatan nasional yang berkelanjutan.

\section{International Fisher Effect (IFE)}

International fisher effect (IFE) digunakan dalam memprediksi pendekatan moneter yang menjelaskan hubungan jangka panjang antara inflasi dan suku bunga. Teori IFE menunjukkan bahwa perbedaan suku bunga dapat digunakan sebagai perkiraan untuk perubahan nilai tukar masa depan (Khawaga dkk., 2013). Perubahan nilai tukar ini pada akhirnya berpengaruh pada keputusan investasi asing, peluang ekspor, dan daya saing harga impor asing. Menurut Krugman dan Obstfeld (2005) jika semua kondisi lain tetap, kenaikan perkiraan tingkat inflasi suatu negara pada akhirnya akan menimbulkan kenaikan suku bunga dari simpanan mata uang negara yang bersangkutan. Sebaliknya, penurunan perkiraan inflasi pada gilirannya akan mengakibatkan penurunan suku bunga atas simpanan mata uang negara itu. Teori IFE menggambarkan bahwa depresiasi mata uang di pasar valuta asing terjadi manakala suku bunganya meningkat jika dibandingkan dengan suku bunga mata uang lain.

\section{METODE}

\section{Uji Stasioneritas}

Uji stasioneritas atau uji akar unit digunakan untuk melihat kestasioneran data deret waktu (times series). Alfian (2011) data time series dikatakan tidak stasioner jika secara stokastik nilai mean, variance, dan covariance menunjukkan pola yang konstan dari waktu ke waktu atau dengan kata lain tidak terdapat peningkatan atau penurunan data. Penggunaan data yang tidak stasioner akan menghasilkan regresi palsu atau lancung (spuriuos regression). Gujarati (2012) menjelaskan bahwa spurious regression yaitu regresi yang menggambarkan hubungan dua variabel atau lebih yang nampaknya signifikan secara statistik padahal kenyataannya tidak, atau tidak sebesar regresi yang dihasilkan tersebut. Uji stasioneritas data, dalam penelitian ini menggunakan The Augmented Dicky Fuller $(A D F)$ test. ADF test pada dasarnya melakukan estimasi terhadap persamaan regresi, sebagai berikut:

$$
\begin{gathered}
\Delta Y_{t}=\mathrm{v}+\gamma Y_{t-1}+\partial_{1} \Delta Y_{t-1}+\partial_{2} \Delta Y_{t-2}+\ldots+ \\
\partial_{p} \Delta Y_{t-p}+\varepsilon_{t}
\end{gathered}
$$

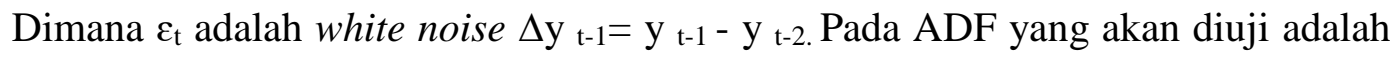
apakah $\gamma=0$ dengan hipotesis alternatif $\gamma<0$, jika nilai absolut dari nilai thitung untuk $\gamma$ lebih besar dari nilai absolut, maka hipotesis nol yang mengatakan bahwa data tidak stasioner ditolak terhadap hipotesis alternatifnya.

\section{Penentuan Lag}

Menurut Alfian (2011) selain mempengaruhi dirinya sendiri, suatu variabel juga dapat berpengaruh terhadap variabel lain. Pengaruh ini harus dalam rentang waktu yang tepat, tidak terlalu lama ataupun cepat. Hal ini bertujuan agar estimasi yang dihasilkan dapat menggambarkan kondisi yang sebenarnya. 
Menurut Al-Arif dan Tohari (2006) penentuan lag length optimal pada penelitian ini menggunakan pemilihan criteria information yang direkomendasikan dengan metode Final Prediction Error (FPE), Akaike Information Criterion (AIC), Schwarz Criterion (SC) dan Hannan Quinn (HQ). Dalam penentuan lag optimal dengan menggunakan kriteria informasi tersebut, maka dipilih kriteria yang mempunyai nilai absolut paling kecil dan nilai adjusted $-\mathrm{R}^{2}$ paling tinggi.

\section{Model Structural Vector Autoregressive (SVAR)}

Vector Autoreggresive (VAR) digunakan sebagai sebuah sistem peramalan dari variabel time series yang saling berhubungan dan digunakan untuk menganalisis dampak dinamis dari gangguan yang bersifat random di dalam sistem VAR (Widarjono, 2009). Lebih lanjut dijelaskan model VAR dikenal dengan model non-structural atau model tidak teoritis (ateoritis). Model SVAR merupakan pengembangan dari model VAR. Widarjono (2009) menjelaskan bahwa pengembangan dalam model SVAR dilakukan melalui adanya peta hubungan antar variabel yang ada di dalam VAR sehingga perlu adanya penetapan restriksi atas hubungan lintas variabel dalam sistem persamaan tersebut. Batasan atau restriksi ini bertujuan untuk memisahkan pergerakan variabel endogen kedalam beberapa komponen dengan mengacu pada underlying shock, berdasarkan suatu teori. Selain itu, Widarjono (2009) juga menambahkan bahwa SVAR dikenal dengan model VAR yang teoritis atau disebut model VAR yang terestriksi. Penggunaan model ini bertujuan untuk membuktikan suatu teori ekonomi atau untuk mencari dasar teoritis dari suatu shock. Spesifikasi model SVAR dalam reduced form adalah sebagai berikut (Bilmeier dan Bonatot, 2002).

$$
\mathrm{A}_{0} \mathrm{X}_{\mathrm{t}}=\mathrm{A}(\mathrm{L}) \mathrm{X}_{\mathrm{t}-1}+\mathrm{B} \varepsilon_{\mathrm{t}}
$$

Dimana $X t$ adalah vektor dengan lima variabel yang digunakan (FFR, BIRATE, NILAI TUKAR, PDB, IHK); Ao adalah contemporaneous relations antar variabel; $\mathrm{A}(\mathrm{L})$ adalah finite-order matrixpolynomial dengan operator lag $\mathrm{L} ; \varepsilon_{t}$ adalah vector structural disturbance; dan B adalah matriks dengan diagonal bukan nol.

\section{HASIL DAN PEMBAHASAN}

\section{Pengaruh Federal Fund Rate (FFR) terhadap BI Rate}

Berdasarkan analisis yang telah dilakukan, diperoleh hasil bahwa FFR berpengaruh positif dan signifikan terhadap BI rate. Dimana setiap terjadi kenaikan satu persen dalam FFR, maka BI rate akan meningkat sebesar 0,11 persen, begitupula sebaliknya. Penurunan dalam FFR, akan mengakibatkan BI rate turun sebesar 0,11 persen. Sehingga dapat disimpukan bahwa hipotesis satu penelitian ini tidak ditolak.

Pada rentang tahun 2005 sampai 2015 nilai FFR cenderung mengalami penurunan sampai pada kisaran nol persen. Hal ini dikarenakan terjadinya beberapa guncangan ekonomi yang mengakibatkan penurunan kinerja ekonomi AS. Penurunan FFR merupakan bagian dari paket kebijakan moneter AS sebagai upaya The Fed dalam memperbaiki kondisi ekonomi AS yang terus memburuk. Sebagai negara mitra dagangnya, penting bagi Indonesia untuk menjadikan nilai FFR sebagai pertimbangan dalam penetapan BI rate nya. Hal ini terkait dengan mobilitas modal masuk dan keluar. Penurunan pada FFR akan berdampak pada 
penurunan pada BI rate pada kisaran tertentu. Hal ini juga dijelaskan pada deskripsi variabel penelitian yang menunjukkan bahwa nilai $\mathrm{BI}$ rate terus berfluktuasi, tetapi memiliki kecenderungan mengalami penurunan jika disbandingkan dengan periode awal penelitian.

Hasil penelitian ini sesuai dengan teori perekonomian terbuka yang dikemukakan oleh Warjiyo dkk (2003). Teori tersebut menyatakan bahwa penetapan kebijakan moneter di Indonesia tidak dapat berjalan secara independen sebagai negara dengan sistem ekonomi terbuka karena harus mempertimbangkan kondisi ekonomi negara lain yang menjadi mitra kerjasamanya. Selain itu hasil penelitian ini juga sejalan dengan model Mundell Fleming yang dikemukakan oleh Mankiw (2007) yang intinya Indonesia merupakan negara yang terlibat dalam aktivitas ekonomi dunia baik dalam perdagangan maupun pasar keuangan dunia akibatnya suku bunga Indonesia sedikit banyak akan terpengaruh oleh suku bunga dunia (FFR).

Penelitian terdahulu juga menunjukkan hasil serupa, seperti yang dilakukan oleh Siahaan dan Hidayat (2013) dimana keduanya menguji hubungan antara FFR dan BI rate dengan menggunakan model VAR. Pada uji kointegrasi, hasilnya FFR dan BI rate memiliki hubungan keseimbangan jangka panjang. Sedangkan, pada uji kausalitas diperoleh hasil bahwa antara dua variabel memiliki hubungan searah yaitu FFR berpengaruh signifikan terhadap BI rate. Pengaruh ini pada dasarnya terbentuk sebagai upaya Indonesia dalam meminimalkan dampak negatif akibat guncangan global yang direpresentasikan oleh perubahan FFR. Peningkatan FFR mengakibatkan terjadinya capital outflow dalam jumlah besar di Indonesia, karena pemilik modal memiliki kecenderungan menempatkan dananya pada sektor yang memberikan timbal hasil lebih besar. Dengan turut meningkatkan BI rate akan menjaga aliran modal dalam negeri tetap stabil.

\section{Implikasi BI Rate terhadap Indikator Makro Ekonomi Implikasi BI Rate terhadap Nilai Tukar (Rp/USD)}

Hasil dari serangkaian analisis yang telah dilakukan, menunjukkan bahwa FFR berpengaruh negatif dan signifikan terhadap nilai tukar. Dimana setiap kenaikan satu persen FFR, nilai tukar akan turun sebesar Rp 964 atau dengan kata lain nilai Rupiah terapresiasi oleh USD. Sebaliknya, manakala terjadi penurunan pada FFR maka nilai Rupiah akan cenderung mengalami depresiasi. Sedangkan, implikasi BI rate terhadap nilai tukar berpengaruh positif signifikan. Setiap terjadi kenaikan satu persen dalam BI rate, maka nilai tukar akan meningkat sebesar Rp 554 atau dengan kata lain nilai tukar Rupiah terdepresiasi oleh USD. Begitupula sebaliknya, manakala terjadi penurunan pada BI rate, nilai Rupiah akan mengalami apresiasi. Sehingga dapat disimpukan bahwa hipotesis dua penelitian ini tidak ditolak.

Selama periode penelitian, nilai BI rate cenderung mengalami penurunan jika dibandingkan dengan periode awal penelitian. Salah satu penyebab penurunan ini yaitu sebagai respon terhadap kebijakan ekspansif dunia (penurunan FFR). Di sisi lain, fluktuasi BI rate terjadi akibat kebutuhan akan stabilisasi dalam negeri. Sehingga, pada akhirnya akan mempengaruhi nilai tukar sebagai salah satu indikator moneter dalam negeri. Deskripsi variabel juga menunjukkan tren nilai tukar yang memiliki kecenderungan meningkat setiap tahunnya atau dengan kata 
lain jika dibandingkan dari awal peride penelitian, nilai Rupiah terus mengalami depresiasi terhadap USD.

Pengaruh langsung FFR terhadap nilai tukar, sesuai dengan teori International Fisher Effect dalam Khawaga, dkk (2013), dimana teori tersebut menjelaskan bahwa selisih suku bunga dua negara berkaitan erat dengan ekspektasi perubahan nilai tukar kedua negara tersebut. Bjorland (2008) menambahkan bahwa satu kebijakan yang dapat diambil untuk mengimbangi depresiasi nilai tukar yaitu dengan meningkatkan tingkat suku bunga acuan (BI rate) agar nilainya terapresiasi dan dapat menahan pelarian modal ke luar negeri. Namun, implikasi BI rate terhadap nilai tukar bertolak belakang dengan teori yang ada, dimana hasil penelitian menunjukkan hubungan positif antara BI rate dan nilai tukar. Khawaga, dkk (2013) menjelaskan bahwa penyesuaian nilai tukar mengakibatkan perbedaan suku bunga dari waktu ke waktu. Ketika tingkat bunga domestik meningkat terhadap suku bunga asing, permintaan terhadap mata uang domestik akan menurun yang menyebabkan mata uang tersebut terdepresiasi. Hal ini didasarkan pada anggapan bahwa penyesuaian harga barang lebih lambat dari waktu ke waktu dari harga aset keuangan. Atau dengan kata lain, pengaruh tingkat suku bunga terhadap nilai tukar membutuhkan waktu (lag).

Penelitian terdahulu juga menunjukkan hasil sama, seperti yang dilakukan oleh Al-Arif dan Tohari (2006) dimana dalam penelitian ini menguji hubungan FFR dan nilai tukar menggunakan metode SVAR. Hasilnya, guncangan FFR memberikan pengaruh terhadap nilai tukar dengan pola hubungan yang negatif signifikan. Selain, itu penelitian yang dilakukan oleh Juoro (2013) juga memberi hasil serupa, dimana penurunan BI rate mengakibatkan apresiasi terhadap nilai tukar riil dengan didahului oleh depresiasi terlebih dahulu (apresiasi nilai tukar membutuhkan waktu/lag). Tingginya BI rate akan mengakibatkan peningkatan pada capital inflow, sehingga permintaan terhadap Rupiah juga akan meningkat pada akhirnya akan mengalami apresiasi, begitupula sebaliknya.

\section{Implikasi BI Rate terhadap Produk Domestik Bruto (PDB)}

Selanjutnya, diperoleh hasil penelitian bahwa FFR berpengaruh negatif namun tidak signifikan terhadap pertumbuhan PDB. Selain itu, implikasi BI rate terhadap pertumbuhan PDB berpengaruh positif namun juga tidak signifikan. Sedangkan, nilai tukar berpengaruh negatif dan signifikan terhadap pertumbuhan PDB. Sehingga dapat disimpukan bahwa hipotesis dua dalam penelitian ini ditolak.

Pada tahun 2005 sampai 2015 nilai pertumbuhan PDB cenderung mengalami fluktuasi. Namun secara riil, nilai PDB terus meningkat setiap tahunnya. Hal ini menandakan terjadinya peningkatan kegiatan ekonomi dari tahun ke tahun atau dengan kata lain jumlah konsumsi maupun produksi terus mengalami peningkatan. Tingginya pertumbuhan ekonomi sebuah negara yang berkelanjutan menunjukkan keberhasilan dalam implementasi kebijakankebijakan yang telah ditetapkan, salah satunya melalui BI rate. Tingginya tingkat FFR harus diimbangi dengan peningkatan BI rate sehingga dapat mencegah capital outflow yang berlebihan. Manakala hal ini tidak dilakukan, maka akan terjadi ketidakstabilan kinerja makroekonomi dalam negeri dengan terdepresiasinya nilai tukar, menurunnya kinerja ekspor, dan pada akhirnya menurunkan pertumbuhan ekonomi dalam negeri. 
Secara teoritis, pengaruh guncangan FFR terhadap pertumbuhan PDB tidak dapat terjadi secara langsung. Pengaruh ini membutuhkan jalur transmisi yang salah satunya dapat terjadi melalui tingkat suku bunga domestiknya (BI rate). Namun dalam penelitian ini BI rate tidak memberikan pengaruhnya terhadap pertumbuhan $\mathrm{PDB}$, selain itu arah hubungan dua variabel ini juga bertolak belakang dengan teori yang ada. Menurut Samuelson dan Nordhaus (2004) menjelaskan bahwa diantara tingkat suku bunga dan pertumbuhan ekonomi memiliki hubungan negatif, dimana tingginya tingkat suku bunga akan diiringi dengan kredit yang ketat serta penurunan kekayaan. Hal ini akan berdampak pada penurunan daya beli dan produksi, sehingga nilai PDB akan cenderung menurun. Salah satu penyebab perbedaan di antara hasil penelitian dan teori yang ada dikarenakan kebijakan moneter di Indonesia pada dasarnya hanya memiliki satu sasaran tunggal yaitu penargetan inflasi (inflation targetting). Warjiyo, dkk (2003) menjelaskan bahwa penetapan sasaran tunggal ini dilakukan karena tidak semua sasaran dapat tercapai secara optimal dengan satu kebijakan saja. Pada umumnya usaha untuk mendorong pertumbuhan ekonomi dan memperluas lapangan pekerjaan akan berdampak pada tingginya harga yang direpresentasikan melalui tingkat inflasi yang semakin tinggi. Penargetan inflasi diharapkan dapat menjadi stabilitas harga dalam jangka panjang dan pertumbuhan ekonomi dalam jangka pendek.

Satu-satunya variabel yang mempengaruhi pertumbuhan PDB dalam penelitian ini yaitu nilai tukar. Dimana setiap terjadi kenaikan nilai tukar (depresiasi), maka pertumbuhan PDB akan mengalami peningkatan. Samuelson dan Nordhaus (2004) menjelaskan pada perdagangan internasional tingginya suku bunga mengakibatkan nilai tukar mengalami apresiasi yang berdampak pada penurunan ekspor sehingga output (PDB riil) akan menurun. Hasil penelitian ini tentunya berbeda dengan beberapa penelitian terdahulu yang dilakukan oleh AlArif dan Tohari (2006) dengan hasil kebijakan moneter sangat signifikan mendorong pertumbuhan ekonomi. Selanjutnya, penelitian yang dilakukan Amaluddin (2010) dengan hasil tingkat suku bunga dan output memiliki hubungan kausalitas dua arah atau saling mempengaruhi.

\section{Implikasi BI Rate terhadap Indeks Harga Konsumen (IHK)}

Hasil analisis yang telah dilakukan juga menunjukkan bahwa FFR berpengaruh negatif namun tidak signifikan terhadap IHK. Selain itu, implikasi BI rate terhadap IHK juga berpengaruh negatif dan tidak signifikan. Variabel nilai tukar juga memberi pengaruh positif dan tidak signifikan terhadap pertumbuhan IHK. Satu-satunya variabel yang berpengaruh signifikan terhadap IHK yaitu pertumbuhan PDB, dimana pengaruhnya bersifat positif dan signifikan. Sehingga dapat disimpukan bahwa hipotesis dua dalam penelitian ini juga ditolak.

Selama rentang waktu tahun 2005 sampai 2015 nilai IHK cenderung berfluktuasi tidak mengikuti tren pergerakan suku bunga dunia maupun domestik yang cenderung mengalami penurunan, selain itu juga tidak mengikuti pergerakan variabel nilai tukar yang mengalami peningkatan; dari tahun ke tahun. Pola pergerakan IHK cenderung naik-turun menyerupai pergerakan pertumbuhan PDB.

Penetapan kebijakan moneter pada dasarnya ditujukan untuk pengendalian harga dalam jangka panjang dan keberlanjutan pertumbuhan ekonomi dalam jangka pendek. Namun, kondisi yang berlawanan ditunjukkan pada hasil 
penelitian bahwa FFR dan BI rate tidak memiliki pengaruh signifikan terhadap IHK. Selain, itu nilai tukar juga memiliki hasil serupa yang juga tidak berpengaruh signifikan terhadap IHK. Warjiyo dkk (2003) menjelaskan bahwa implementasi kebijakan moneter terkadang tidak dapat secara langsung mencapai target yang telah ditetapkan, melainkan membutuhkan jalur transmisi. Mekanisme transmisi kebijakan moneter dapat terjadi melalui lima jalur diantaranya, Jalur suku bunga, nilai tukar, harga aset, kredit, dan jalur ekspektasi. Terkait hasil penelitian yang menunjukkan bahwa suku bunga dan nilai tukar tidak mempengaruhi pergerakan IHK, maka dapat disimpulkan bahwa kebijakan moneter dapat mencapai tujuan stabilitas harga melalui tiga jalur transmisi lainnya, yaitu jalur harga aset, kredit, dan ekspektasi.

Satu-satunya variabel yang mempengaruhi IHK secara signifikan yaitu pertumbuhan PDB dimana setiap terjadi kenaikan satu persen PDB maka nilai IHK akan meningkat sebesar 0,53 persen. Hal ini sesuai dengan teori makroekonomi Dornbusch, Fischer, dan Startz (2008) yang menyatakan bahwa PDB merupakan bagian dari pendapatan nasional suatu negara yang memiliki pengaruh positif terhadap inflasi, dimana kenaikan dalam PDB menandakan kenaikan pula pada permintaan nasional. Kenaikan tersebut akan diikuti dengan kenaikan konsumsi masyarakat, sehingga hal ini menjadi faktor pendorong kenaikan harga-harga barang yang berakibat pada inflasi. Terkait hal tersebut hasil penelitian ini bertolak belakang dengan penelitian terdahulu yang dilakukan oleh Wahyudi (2014) yang menyatakan bahwa dalam jangka pendek dan panjang BI rate berpengaruh signifikan terhadap laju inflasi, namun BI rate kuartal sebelumnya memberikan hasil yang tidak signifikan terhadap inflasi. Sementara itu, hasil penelitian ini juga menunjukkan bahwa PDB dalam jangka pendek dan panjang tidak berpengaruh signifikan terhadap inflasi, sedangkan PDB kuartal sebelumnya memberikan hasil yang signifikan terhadap inflasi.

\section{KESIMPULAN}

Berdasarkan pembahasan di atas dapat disimpulkan bahwa Federal Fund Rate berpengaruh positif signifikan terhadap BI rate. Indonesia merupakan negara yang terlibat dalam aktivitas ekonomi dunia baik dalam perdagangan maupun pasar keuangan dunia akibatnya suku bunga Indonesia sedikit banyak akan terpengaruh oleh suku bunga dunia (FFR). Selain itu BI rate berpengaruh positif signifikan terhadap nilai tukar. Selain itu, BI rate berpengaruh positif namun tidak signifikan terhadap PDB. Selanjutnya, BI rate berpengaruh negatif dan tidak signifikan terhadap IHK. Ketika tingkat bunga domestik meningkat terhadap suku bunga asing, permintaan terhadap mata uang domestik akan menurun yang menyebabkan mata uang tersebut terdepresiasi. Hal ini didasarkan pada anggapan bahwa penyesuaian harga barang lebih lambat dari waktu ke waktu dari harga aset keuangan. Atau dengan kata lain, pengaruh tingkat suku bunga terhadap nilai tukar membutuhkan waktu (lag).

Dari penjelasan tersebut disarankan bagi pengambil kebijakan diharapkan dapat lebih responsif dalam merespon perubahan kebijakan moneter dunia khususnya melalui pergerakan tingkat suku bunganya. Perubahan dalam FFR menandakan terjadinya perubahan pada kinerja ekonomi AS, dengan turut merubah BI rate akan dapat meminimalkan dampak negatif yang akan ditimbulkan. Kesalahan dalam pengambilan kebijakan dapat mengganggu 
stabilitas variabel makroekonomi dalam negeri meliputi tingkat harga, nilai tukar, dan pertumbuhan ekonomi. Selain itu, diharapkan penetapan kebijakan moneter melalui BI rate, tidak hanya digunakan dalam pengendalian inflasi dalam jangka panjang dan pertumbuhan ekonomi berkelanjutan dalam jangka pendek tetapi juga memperhatikan stabilitas nilai tukar. Hal ini dapat dilakukan melalui instrumen kebijakan moneter lainnya seperti Operasi Pasar Terbuka (menjual atau membeli valas-USD).

\section{DAFTAR RUJUKAN}

Al-Arif, M. M., \& Tohari, A. (2006). Peranan Kebijakan Moneter Dalam Menjaga Stabilitas Perekonomian Indonesia Sebagai Respon Terhadap Fluktuasi Perekonomian Dunia. Buletin Ekonomi Moneter dan Perbankan, 9(2), 145-177.

Alfian, M. (2011). Efektifitas Mekanisme Transmisi Kebijakan Moneter Pada Jalur Suku Bunga Periode 2005:07-2010:06. Media Ekonomi, 19(2), 89115.

Amaluddin. (2010). Kebijakan Moneter, Investasi Swasta Dan Tingkat Output di Indonesia: Suatu Aplikasi Granger Causality Test, Periode 1999-2009. Jurnal Citra Ekonomika, 4(2), 91-111.

Asari, A, H., Fizari, F., Baharuddin, N.Y., Jusoh, N., Mohamad, Z., Shamsudin, N., \& Jusoff, K. (2011). A Vector Error Correction Model (VECM) Approach in Explaining the Relationship Between Interest Rate and Inflation Towards Exchange Rate Volatility in Malaysia. World Applied Sciences Journal 12: 49-56.

Atmadja, A.S. (2001). Free Floating Exchange Rate System Dan Penerapannya Pada Kebijaksanaan Ekonomi di Negara Yang Berperekonomian Kecil Dan Terbuka. Jurnal Akuntansi dan Keuangan, 3(1), 18-29.

Badan Pusat Statistik. (2016). Ekspor-Impor. Retrieved from www.bps.go.id.

Bank Indonesia. (2016). Laporan Perekonomian Indonesia Tahun 2016. Retrieved from www.bi.go.id.

Bilmeier, A., \& Bonato, L. (2002). Exchange rate Pass-Through and Monetary Policy in Croatia. IMF Working Paper.

Bjorland, H. C. (2008). Monetary Policy and Exchange Rate Interactions in a Small Open Economy. Scaninavian. Journal of Economics, 110(1), 197221.

Bodenstein, M., Christopher, J. E., \& Luca Guerrieri. (2009). The Effects of Foreign Shocks when Interest Rates are at Zero. International Finance Discussion Papers 983. Retrieved from www.federalreserve.gov/../IFDP983.pdf.

Gujarati, D. N. (2012). Dasar-Dasar Ekonometrika. Jakarta: Salemba Empat.

Hermawan, I. (2011). Analisis Kebijakan Makroekonomi Terhadap Perkembangan Industri Tekstil dan Produksi Tekstil Indonesia. Buletin Ekonomi Moneter dan Perbankan, 13(4), 373-408.

Hilton, S., \& Warren B. H. (2007). Reserve Levels and Intraday Federal Funds Rate Behavior. Federal Reserve Bank of New York Staff Reports, 284. Retrieved from www.newyorkfed.org/../sr284.pdf. 
Ibrahim, T.W., Melva, V., \& Yanfitri. (2014). Transmisi Dampak Melalui Jaringan Perdagangan: Pendekatan Asian-IO. Buletin Ekonomi Moneter dan Perbankan, 16(4), 339-372.

Juoro, U. (2013). Model Kebijakan Moneter Dalam Perekonomian Terbuka Untuk Indonesia. Buletin Ekonomi Moneter dan Perbankan, 16(1), 81-97.

Kementrian Perdagangan RI. (2013). Analisis Dampak Kebijakan Fiscal Cliff Amerika Serikat. Retrieved from www.kemendag.go.id/files/pdf/2015/0... diakses Desember 2015.

Khawaga, A.E., Esam, M., \& Hammam, R. (2013). Exchange Rates and Interest Rates: An Empirical Investigation of International Fisher Effect Theory The Case of Egypt (2003-2012) International Research Journal of Finance and Economics, 117, 139-160.

Krugman, P. R. \& Maurice Obsfeld. (2005). Ekonomi Internasional Teori dan Kebijakan. Jakarta: PT Indeks Kelompok Gramedia.

Mankiw, N. G. (2007). Makroekonomi. Jakarta: Erlangga.

Mishkin, F. S. (2008). Ekonomi Uang, Perbankan, dan Pasar Keuangan (Buku 2, Edisi 8). Jakarta: Salemba Empat.

Nezky, M. (2013). Pengaruh Krisis Ekonomi Amerika Serikat Terhadap Bursa Saham Dan Perdagangan Indonesia. Buletin Ekonomi Moneter dan Perbankan, 15(3), 89-103.

Nizar, M. A. (2012). The Impact of World Oil Prices Fluctuation on Indonesia's Economy. Munic Personal Repec Archive No. 65601. Retrieved from https://mpra.ub.uni-muenchen.de/65601/1/MPRA_paper_65601.pdf.

Samuelson, P. A., \& William D. N. (2004). Ilmu Makroekonomi. Jakarta: PT. Media Global Edukasi.

Siahaan, L.M., \& Hidayat, P. (2013). Analisis Kausalitas Antara Tingkat Suku Bunga Bank Indonesia (BI Rate) Dengan Suku Bunga Amerika Serikat (The Fed). Jurnal Ekonomi dan Keuangan, 1(8), 49-60.

Sudarjah, G.M., \& Yusuf, A. (2008). Kebijakan Moneter (BI Rate) Dalam Pengendalian Harga (Inflasi). Trikonomika, 7(2), 141-149.

Wahyudi, E. (2014). Pengaruh Suku Bunga Bank Indonesia (BI Rate) dan Produk Domestik Bruto (PDB) terhadap Laju Inflasi di Indonesia Periode Tahun 2000.1-2013.4. retieved from (download.portalgaruda.org/article.p...)

Warjiyo, Perry, F.X. Sugiyono, Suseno, Hotbin S., Iskandar, Ascarya, Suarpika B., Piter A., dan Solikin. (2003), Bank Indonesia: Tinjauan Kelembagaan, Kebijakan, dan Organisasi. Jakarta: Pusat Pendidikan dan Kebanksentralan.

Widarjono, A. (2009). Ekonometrika Pengantar dan Aplikasinya. Yogyakarta: EKONISIA Fakultas Ekonomi UII.

Woodford, M. (2001). The Taylor Rule and Optimal Monetary Policy. Working paper retrieved from www.columbia.edu/mw2230/taylor.pdf. 